\title{
Does Retaining Third Molars Result in the Development of Pathology Over Time? A Systematic Review
}

\author{
Cedric Vandeplas, DDS, MSc, ${ }^{*}$ Myrthel Vranckx, MSc, PbD,$\dagger$ \\ Dominique Hekner, MD, DDS, MSc, $\ddagger$ \\ Constantinus Politis, PhD, MD, DDS, $\S$ and Reinhilde Jacobs, PhD, DDS/
}

Purpose: The present systematic review was conducted to assess the available literature on pathologies associated with third molar retention.

Materials and Methods: A systematic literature search was conducted in MEDLINE (PubMed), Embase, and Cochrane Library and reported in accordance with the Preferred Reporting Items for Systematic reviews and Meta-Analyses guidelines. Relevant reports were selected using predefined inclusion and exclusion criteria. Pathology related to third molar retention included caries, periodontal pathology, second molar external root resorption, and pathologic widening of the third molar pericoronal space. The methodologic quality of each study was reviewed using a pathology-specific tool to assess the risk of bias.

Results: A total of 37 studies were included for qualitative analysis. The available data showed that asymptomatic retained third molars frequently become diseased with increasing age of the patient and increased retention time. Caries and periodontal pathology were most frequently observed, especially in partially erupted third molars and mesially inclined mandibular third molars. Overall, the available data were regarded as medium to fair quality evidence.

Conclusions: The available data have revealed that retained asymptomatic third molars rarely remain disease-free over time. Increasing age and, thus, increasing retention time seemed associated with greater disease prevalence. Well-designed, prospective follow-up studies are needed to substantiate the clinical management of asymptomatic disease-free third molars.

(C) 2020 American Association of Oral and Maxillofacial Surgeons

J Oral Maxillofac Surg $\mathbf{\square}: 1-17,2020$

*Researcher, Oral and Maxillofacial Surgery - Imaging and Pathology Research Group, Department of Imaging and Pathology, Faculty of Medicine, University of Leuven, and Department of Oral and Maxillofacial Surgery, University Hospitals Leuven, Leuven, Belgium.

$\dagger$ Researcher, Oral and Maxillofacial Surgery - Imaging and Pathology Research Group, Department of Imaging and Pathology, Faculty of Medicine, University of Leuven, and Department of Oral and Maxillofacial Surgery, University Hospitals Leuven, Leuven, Belgium.

†Surgical Resident, Department of Oral and Maxillofacial Surgery, Radboud University Medical Center, Nijmegen, The Netherlands.

$\S$ Department Head, Oral and Maxillofacial Surgery - Imaging and Pathology Research Group, Department of Imaging and Pathology, Faculty of Medicine, University of Leuven, and Department of Oral and Maxillofacial Surgery, University Hospitals Leuven, Leuven, Belgium.

||Coordinator Research Group, Oral and Maxillofacial Surgery Imaging and Pathology Research Group, Department of Imaging and Pathology, Faculty of Medicine, University of Leuven; Department of Oral and Maxillofacial Surgery, University Hospitals Leuven, Leuven, Belgium; and Professor, Department of Dental Medicine, Karolinska Institutet, Stockholm, Sweden.

Drs Vandeplas and Vranckx contributed equally to this article.

Conflict of Interest Disclosures: None of the authors have any relevant financial relationship(s) with a commercial interest.

Address correspondence and reprint requests to Dr Vranckx: Oral and Maxillofacial Surgery - Imaging and Pathology Research Group, Department of Imaging and Pathology, Faculty of Medicine, University of Leuven, and Department of Oral and Maxillofacial Surgery, University Hospitals Leuven, Kapucijnenvoer 7 blok A, Leuven 3000, Belgium; e-mail: Myrthel.vranckx@kuleuven.be

Received May 82020

Accepted June 62020

(C) 2020 American Association of Oral and Maxillofacial Surgeons

0278-2391/20/30588-7

https://doi.org/10.1016/i.joms.2020.06.014 
Third molars (wisdom teeth) have often been viewed as "ticking time bombs" that have little to no masticatory function and will often only partially erupt or, even, remain completely unerupted in the dental arch. Thus, removal of third molars has been one of the most commonly performed procedures by oralmaxillofacial surgeons. Failure of a tooth to reach a normal functional position in the occlusion is termed impaction and can result from a lack of space or development of the tooth germ in an abnormal position. The worldwide prevalence of third molar impaction has been estimated to be $24 \%$, greater than that for any other teeth. ${ }^{1}$ Although impaction itself is not considered a pathology, it has been associated with several pathologies that might indicate the necessity for the removal of the impacted tooth, such as infection, nonrestorable carious lesions, periodontal pathology, root resorption, pericoronitis, cysts, and tumors. Other surgical indications have included removal before chemotherapy or radiation therapy, removal in the context of orthodontic or prosthodontic treatment, preparation for orthognathic surgery, and cases in which the third molar will be used for tooth autotransplantation.

Clinicians have agreed that for such cases, or when symptoms arise, third molar removal will generally be justified. However, the management of third molars when free of pathology (also denoted as prophylactic removal) has been debated for many decades. ${ }^{2}$ Several international guidelines have been reported on this topic, including the 2000 National Institute for Health and Care Excellence (NICE) guidelines from the United Kingdom, the 2000 Scottish Intercollegiate Guidelines Network (SIGN) guidelines, and the 2012 Belgian Health Care Knowledge Centre (KCE) report. ${ }^{3-5}$ Generally, these guidelines have advocated a conservative approach to pathologyfree impacted third molars because it has remained uncertain whether these teeth will eventually develop pathology that would require removal. Given the economic and personal costs involved, it is understandable how the validity of this procedure has been called into question. It is evident that the choice of the clinician should be based on their expertise, the individual needs of the patient, and the best research available. However, it is also evident that the reported studies have not provided a clear answer and that a regular need exists to update current prevailing positions in accordance with the best available research. The present systematic review was conducted to assess the reported data on the pathologies associated with third molar retention.

\section{Materials and Methods}

The present systematic review was conducted and reported in accordance with the principles of the
Preferred Reporting Items for Systematic Reviews and Meta-Analyses (PRISMA) to ensure comprehensiveness. ${ }^{6}$ The review was registered at the Prospective Register of Systematic Reviews (registry no. CRD42018102034).

\section{INFORMATION SOURCES AND SEARCH STRATEGY}

The search strategy was designed to determine the pathologies associated with the retention of (asymptomatic) third molars and the quality of the available evidence regarding retention and prophylactic removal. The search strategy was constructed for PubMed (MEDLINE) and adapted for Embase and the Cochrane Library. The reference lists of previous systematic reviews were screened for additional relevant reports. The full search syntax has been provided be in Appendix 1. MeSH or EMTREE terms and keywords were combined to ensure that all relevant studies would be included. The search strategy was constructed to obtain data on third molars and the occurrence of oral pathologies. These were narrowed down during screening to the 4 most common pathologies related to third molars. Only English language studies were included. Duplicate reports were manually checked and removed.

\section{INCLUSION AND EXCLUSION CRITERIA}

All identified studies were screened by 2 authors (M.V., D.H.) using the title, abstract, and full-text with reference to the inclusion criteria. In all phases of screening, disagreements were resolved by discussion between the 2 reviewers. When a consensus could not be reached, an experienced third author (R.J.) was consulted.

The inclusion criteria were as follows:

1. Studies investigating a human population with the presence of at least 1 third molar in a longitudinal or cross-sectional study design

2. Studies investigating the prevalence and/or incidence of pathology related to the presence and/or third molar retention using clinical and/ or radiographic evaluation

3. Studies reporting sufficient information to extract data for the measured outcomes

Review articles, case reports, case series, expert opinions, letters, and editorials were excluded from the present analysis.

\section{DATA EXTRACTION}

The relevant data were extracted from the reports by 3 authors (C.V., M.V., D.H.). The primary outcome measures were the prevalence, incidence, and relative risks of pathologic conditions. Pathology was defined 
as dental caries of the third molar or the distal portion of the second molar, periodontal pathology (ie, clinical attachment loss, alveolar bone loss) of the third molar or distal to the second molar, external root resorption (ERR) of the second molar, and pathologic widening of the third molar pericoronal space. The extracted data included the study and sample characteristics (ie, authors, year of publication, sample number, sample age, number of third molars, state of eruption), methods (ie, study design, methods of measurement, follow-up time), and outcome measures (ie, investigated pathologies, results, conclusions). $P$ values $<.05$ were considered statistically significant.

\section{ASSESSMENT OF STUDY QUALITY}

All included studies were evaluated for methodologic validity using a risk of bias tool inspired by the Cochrane Collaboration's (CC) tool. ${ }^{7}$ We had modified the CC tool to ensure an optimal fit for the included studies. The risk of bias was assessed across 4 domains and 5 topics: selection (study population), detection (standardization and method of measurement), attrition (incomplete data), and reporting (selective reporting). Of the 5 topics, 4 were adopted from the original CC tool. Additionally, we constructed a pathology-specific assessment of the methodologic quality (method of measurement). Every report was assessed for each of the potential biases and scored 2, 1 or 0 , indicating a low, medium, and high risk of bias, respectively. For each pathology, the mean quality scores were calculated per the topic of bias. All assessments were performed by 2 authors (C.V., M.V.). Disagreements were resolved by discussion between the 2 authors.

\section{Results}

The complete selection process is displayed in a PRISMA flow chart (Fig 1). Searching the MEDLINE, Embase, and Cochrane Library databases identified $8,682,8,015$, and 1,538 records, respectively. After removal of duplicates, 9,163 unique studies were identified. A selection of 151 reports remained after title screening. Additionally, 98 reports were removed because the abstract failed to meet the inclusion criteria. After strictly applying the inclusion and exclusion criteria, 37 reports were selected for analysis and quality assessment. ${ }^{8-44}$

\section{STUDY CHARACTERISTICS}

A detailed overview of the study characteristics is provided in Table 1 . The included studies had been reported from 1989 to 2019 . Of the 37 studies, 12 were prospective cohort studies, 1 was a retrospective cohort study, and 24 were cross-sectional studies (Table 1). The follow-up time for the prospective cohort studies was 2.2 to 6.9 years (mean, 4.0 years), with 1 outlier reporting a follow-up period of more than 25 years. $^{32}$ The retrospective cohort study had a median follow-up time of 7.7 years (mean, not reported). ${ }^{35}$ Of the 37 studies, 21 collected data from a subsample of a previously conducted prospective cohort study (Table 1), and 15 examined patients from their own department or practice. The remaining study examined the records of British military personnel. ${ }^{35}$ In 16 studies, the dataset originating from a longitudinal trial at the University of Kentucky and University of North Carolina had been used. ${ }^{10-13,44}$ Other datasets used in the present review included the Piedmont 65+ Dental Study, US Department of Veterans Affairs Dental Longitudinal Study, Third National Health and Nutrition Survey (NHANES III), Dental Atherosclerosis Risk in Communities (ARIC) study, Helsinki Aging Study, and Finland Health 2000 Survey. The total number of subjects included in the present review was $47,876(3,783$ in the cohort studies and 44,093 in the cross-sectional studies). However, because several studies used subsamples of the same dataset, the actual total number of unique subjects could not be determined precisely (but was likely $\sim 2500$ subjects). The overall mean age (mean of the mean) was $36 \pm 15$ years (range, 13 to 93 years). However, 3 studies had not reported a mean age. ${ }^{17,35,40}$ The mean sample size was $1,294 \pm 2067$ (range, 49 to $6,793)$. The total number of third molars across all studies was 17,156 (mean, $953 \pm 1,426$; range, 84 to 5,665 ), although the number of unique third molars was, again, likely to be lower because of reused datasets. Also, 19 studies had not reported the number of investigated third molars.

\section{STUDY METHODS AND OUTCOMES}

Of the 37 studies, 22 investigated caries of the third or second molar, 24 investigated periodontal pathology of the third or second molar, 9 investigated ERR of the second molar, and 5 investigated pathologic widening of the third molar pericoronal space. Also, 23 studies had investigated only 1 of these pathologies, 9 investigated 2, 1 investigated 3 , and 4 investigated 4 pathologies. In 14 studies, the data were collected using both clinical and radiographic examinations. In 11 studies, the data were collected through clinical examination only, and in 12 studies, the data were collected from radiographic examinations only.

\section{DATA RESULTS}

The main conclusions drawn from the included reports are summarized in Table 2, with studies with statistically significant findings marked with an asterisk. The study results varied widely owing to variability in the included samples and methods. 


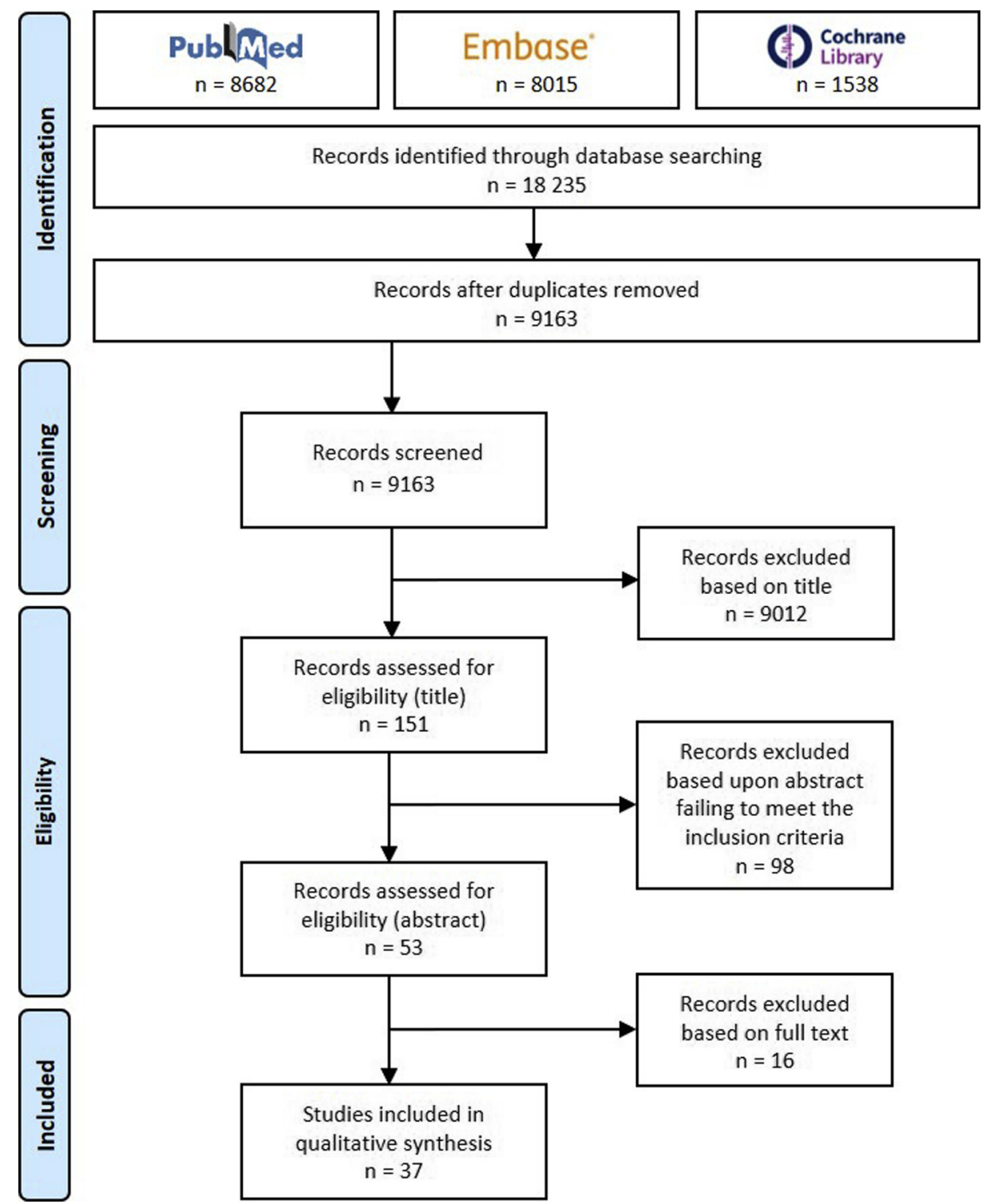

FIGURE 1. Preferred Reporting Items for Systematic Reviews and Meta-Analyses 2009 flow diagram.

Vandeplas et al. Third Molar Retention and Pathology. J Oral Maxillofac Surg 2020.

\section{Caries}

Caries was by far the most observed pathology in the retained third molars. The prevalence ranged from 24 to $80 \%$, depending on the age of the subjects. $^{24,38,41}$ As demonstrated by Shugars et al ${ }^{39}$ in 2005, mandibular third molars were significantly more affected by caries than were maxillary third molars. Several prevalence studies also demonstrated that third molars have an increased risk of developing caries in the case of partial third molar eruption (both upper and lower jaws) and in the case of a mesial third molar inclination in the mandible. ${ }^{23,27,30,34,38}$ Moreover, an association was demonstrated between the presence of a third molar and the risk of caries on the distal side of the second molar (M2D). In a 3- year follow-up of 416 persons (age, 28 to 76 years), Nunn et $\mathrm{al}^{32}$ found that the presence of an erupted third molar increased the risk of caries on the M2D by 2.5 -fold compared with the risk in absence of the third molar. Similar results were reported by Pepper et al, ${ }^{35}$ who investigated a younger population (age, 17 to 18.9 years). They reported a significant increase in M2D caries prevalence when a partially erupted third molar was present (7\%) compared with its absence (3\%). Likewise, a split-mouth study by Chou et $\mathrm{al}^{15}$ of 70 elderly patients showed that caries in the third molar region (M2D and third molar) was significantly more frequent in the third molar group than in the non-third molar group. Chou et $\mathrm{al}^{15}$ concluded that the presence of a third molar is a risk 


\begin{tabular}{|c|c|c|c|c|c|c|c|c|c|c|c|c|}
\hline Design & Investigator & $\begin{array}{l}\text { Mean } \\
\text { Follow- } \\
\text { Up (yr) }\end{array}$ & $\begin{array}{l}\text { Examination } \\
\text { Method }\end{array}$ & Description & $\begin{array}{l}\text { Patients } \\
\text { (n) }\end{array}$ & $\begin{array}{l}\text { Age (yr) } \\
\text { Mean; } \\
\text { Range }\end{array}$ & $\begin{array}{l}\text { Third } \\
\text { Molars } \\
\text { (n) }\end{array}$ & $\begin{array}{l}\text { Eruption } \\
\text { Status }\end{array}$ & Caries & $\begin{array}{c}\text { Periodontal } \\
\text { Pathology }\end{array}$ & $\begin{array}{c}\text { M2 } \\
\text { ERR }\end{array}$ & $\begin{array}{l}\text { Widening } \\
\text { of M3 } \\
\text { Pericoronal } \\
\text { Space }\end{array}$ \\
\hline \multicolumn{13}{|c|}{$\begin{array}{l}\text { Prospective } \\
\text { cohort }\end{array}$} \\
\hline & $\begin{array}{l}\text { Ahmad et al, } \\
\quad 2008\end{array}$ & 5.1 & Clinical & $\begin{array}{l}\text { University of Kentucky } \\
\text { and North Carolina } \\
\text { study subsample }\end{array}$ & 49 & $21 ; 19-39$ & 100 & $\begin{array}{c}\text { Erupted and } \\
\text { impacted }\end{array}$ & Yes & Yes & No & No \\
\hline & $\begin{array}{l}\text { Blakey et al, }^{12} \\
\quad 2006\end{array}$ & 2.2 & $\begin{array}{l}\text { Clinical and } \\
\text { radiographic }\end{array}$ & $\begin{array}{l}\text { University of Kentucky } \\
\text { and North Carolina } \\
\text { study subsample }\end{array}$ & 254 & $28 ; 14-45$ & NA & Erupted & No & Yes & No & No \\
\hline & $\begin{array}{l}\text { Blakey et al, }{ }^{11} \\
2007\end{array}$ & 5.9 & Clinical & $\begin{array}{l}\text { University of Kentucky } \\
\text { and North Carolina } \\
\text { study subsample }\end{array}$ & 195 & $26 ; 22-34$ & NA & Erupted & No & Yes & No & No \\
\hline & $\begin{array}{l}\text { Blakey et al, } \\
\quad 2009\end{array}$ & 4.1 & $\begin{array}{l}\text { Clinical and } \\
\text { radiographic }\end{array}$ & $\begin{array}{l}\text { University of Kentucky } \\
\text { and North Carolina } \\
\text { study subsample }\end{array}$ & 106 & $25 ; 20-32$ & NA & Erupted & No & Yes & No & No \\
\hline & $\begin{array}{l}\text { Divaris et al, }{ }^{18} \\
\quad 2012\end{array}$ & 4.6 & Clinical & $\begin{array}{l}\text { University of Kentucky } \\
\text { and North Carolina } \\
\text { study subsample }\end{array}$ & 215 & $26 ; 14-45$ & NA & Erupted & Yes & No & No & No \\
\hline & $\begin{array}{l}\text { Fisher et al, } \\
\quad 2012\end{array}$ & 6.9 & $\begin{array}{l}\text { Clinical and } \\
\text { radiographic }\end{array}$ & $\begin{array}{l}\text { University of Kentucky } \\
\text { and North Carolina } \\
\text { study subsample }\end{array}$ & 179 & $29 ; 14-45$ & NA & Erupted & Yes & Yes & No & No \\
\hline & $\begin{array}{l}\text { Golden } \\
\text { et al, } \\
2015\end{array}$ & 6 & Clinical & $\begin{array}{l}\text { University of Kentucky } \\
\text { and North Carolina } \\
\text { study subsample }\end{array}$ & 129 & $23 ; 19-28$ & NA & Erupted & No & Yes & No & No \\
\hline & $\begin{array}{l}\text { Moss et al, }{ }^{30} \\
2007\end{array}$ & 3 & Clinical & $\begin{array}{l}\text { Piedmont } 65+\text { Dental } \\
\text { Study subsample }\end{array}$ & 818 & $73 ;>65$ & NA & Erupted & Yes & Yes & No & No \\
\hline & $\begin{array}{l}\text { Nance et al, }{ }^{31} \\
\quad 2006\end{array}$ & 2.2 & Clinical & $\begin{array}{l}\text { University of Kentucky } \\
\text { and North Carolina } \\
\text { study subsample }\end{array}$ & 237 & $26 ; 22-33$ & 948 & Erupted & No & Yes & No & No \\
\hline & $\begin{array}{l}\text { Nunn et al, }{ }^{32} \\
2013\end{array}$ & NA & $\begin{array}{l}\text { Clinical and } \\
\text { radiographic }\end{array}$ & $\begin{array}{l}\text { US Department of } \\
\text { Veterans Affairs Dental } \\
\text { Longitudinal Study } \\
\text { subsample }\end{array}$ & 416 & $46 ; 28-76$ & 344 & $\begin{array}{c}\text { Erupted and } \\
\text { impacted }\end{array}$ & Yes & Yes & No & No \\
\hline
\end{tabular}




\begin{tabular}{|c|c|c|c|c|c|c|c|c|c|c|c|c|}
\hline \multirow[b]{2}{*}{ Design } & \multirow[b]{2}{*}{ Investigator } & \multirow[b]{2}{*}{$\begin{array}{l}\text { Mean } \\
\text { Follow- } \\
\text { Up (yr) }\end{array}$} & \multirow[b]{2}{*}{$\begin{array}{l}\text { Examination } \\
\text { Method }\end{array}$} & \multicolumn{5}{|c|}{ Sample } & \multicolumn{4}{|c|}{ Outcomes } \\
\hline & & & & Description & $\begin{array}{l}\text { Patients } \\
\text { (n) }\end{array}$ & $\begin{array}{l}\text { Age (yr) } \\
\text { Mean; } \\
\text { Range }\end{array}$ & $\begin{array}{l}\text { Third } \\
\text { Molars } \\
\text { (n) }\end{array}$ & $\begin{array}{l}\text { Eruption } \\
\text { Status }\end{array}$ & Caries & $\begin{array}{l}\text { Periodontal } \\
\text { Pathology }\end{array}$ & $\begin{array}{c}\text { M2 } \\
\text { ERR }\end{array}$ & $\begin{array}{l}\text { Pathologic } \\
\text { Widening } \\
\text { of M3 } \\
\text { Pericoronal } \\
\quad \text { Space }\end{array}$ \\
\hline & $\begin{array}{l}\text { Shugars } \\
\text { et al, } \\
2005\end{array}$ & 2.9 & $\begin{array}{l}\text { Clinical and } \\
\text { radiographic }\end{array}$ & $\begin{array}{l}\text { University of Kentucky } \\
\text { and North Carolina } \\
\text { study subsample }\end{array}$ & 211 & $27 ; 23-33$ & NA & Erupted & Yes & No & No & No \\
\hline & $\begin{array}{l}\text { White et al, }{ }^{44} \\
2006\end{array}$ & 2.2 & Clinical & $\begin{array}{l}\text { University of Kentucky } \\
\text { and North Carolina } \\
\text { study subsample }\end{array}$ & 254 & $28 ; 18-24$ & NA & Erupted & No & Yes & No & No \\
\hline $\begin{array}{l}\text { Retrospective } \\
\text { cohort }\end{array}$ & $\begin{array}{l}\text { Pepper et al, }{ }^{35} \\
2017\end{array}$ & $\begin{array}{l}7.7 \\
\text { (median) }\end{array}$ & $\begin{array}{l}\text { Clinical and } \\
\text { radiographic }\end{array}$ & British military personnel & 720 & $\begin{array}{l}18 \text { (median); } \\
17-18\end{array}$ & NA & $\begin{array}{l}\text { Erupted and } \\
\text { impacted }\end{array}$ & Yes & No & No & No \\
\hline \multicolumn{13}{|c|}{$\begin{array}{l}\text { Cross- } \\
\text { sectional }\end{array}$} \\
\hline & $\begin{array}{l}\text { Al Hobail } \\
\text { et al, }{ }^{9} 2019\end{array}$ & NA & $\begin{array}{l}\text { Clinical and } \\
\text { radiographic }\end{array}$ & $\begin{array}{l}\text { Riyadh Elm University } \\
\text { dental clinic patients }\end{array}$ & 313 & $32 ; \geq 25$ & 1,252 & $\begin{array}{l}\text { Erupted and } \\
\text { impacted }\end{array}$ & Yes & No & No & No \\
\hline & $\begin{array}{l}\text { Blakey et al, }{ }^{10} \\
2002\end{array}$ & NA & $\begin{array}{l}\text { Clinical and } \\
\text { radiographic }\end{array}$ & $\begin{array}{l}\text { University of Kentucky } \\
\text { and North Carolina } \\
\text { study subsample }\end{array}$ & 329 & $25 ; 22-32$ & NA & Erupted & No & Yes & No & No \\
\hline & $\begin{array}{l}\text { Celikoglu } \\
\text { et al, }{ }^{14} \\
2010\end{array}$ & NA & Radiographic & $\begin{array}{l}\text { Department of } \\
\text { Orthodontics, } \\
\text { University of Ataturk } \\
\text { patients }\end{array}$ & 351 & $23 ; 20-26$ & 1,161 & Impacted & Yes & Yes & Yes & Yes \\
\hline & $\begin{array}{l}\text { Chou et al, } \\
2017\end{array}$ & NA & $\begin{array}{l}\text { Clinical and } \\
\text { radiographic }\end{array}$ & $\begin{array}{l}\text { Department of } \\
\text { Periodontology and } \\
\text { Dentistry, Kaohsiung } \\
\text { Municipal Ta-Tung } \\
\text { Hospital patients }\end{array}$ & 70 & $45 ; 26-73$ & 81 & Erupted & Yes & Yes & No & No \\
\hline & $\begin{array}{l}\text { Chu et al, }{ }^{16} \\
2003\end{array}$ & NA & $\begin{array}{l}\text { Clinical and } \\
\text { radiographic }\end{array}$ & $\begin{array}{l}\text { Prince Philip Dental } \\
\text { Hospital patients }\end{array}$ & 2081 & $40 ; 14-89$ & 3,778 & Impacted & Yes & Yes & No & No \\
\hline & $\begin{array}{l}\text { Claudia } \\
\text { et al, }{ }^{17} \\
2018\end{array}$ & NA & Radiographic & $\begin{array}{l}\text { Private practice patients, } \\
\text { Constana, Romania }\end{array}$ & 55 & NA; 20-65 & 95 & $\begin{array}{l}\text { Erupted and } \\
\text { impacted }\end{array}$ & Yes & No & No & No \\
\hline & $\begin{array}{c}\text { Eliasson } \\
\text { et al, }{ }^{19} \\
\mathbf{1 , 9 8 9}\end{array}$ & NA & $\begin{array}{l}\text { Clinical and } \\
\text { radiographic }\end{array}$ & $\begin{array}{l}\text { Department of Oral } \\
\text { Radiology patients, } \\
\text { Karolinska Institutet, } \\
\text { Stockholm }\end{array}$ & 644 & $43 ; \geq 30$ & NA & $\begin{array}{l}\text { Erupted and } \\
\text { impacted }\end{array}$ & No & Yes & Yes & Yes \\
\hline
\end{tabular}




\begin{tabular}{|c|c|c|c|c|c|c|c|c|c|c|c|}
\hline $\begin{array}{l}\text { Elter et al, }^{21} \\
2004\end{array}$ & NA & Clinical & $\begin{array}{l}\text { Third National Health } \\
\text { and Nutrition Survey } \\
\text { study subsample }\end{array}$ & 5,831 & $26 ; 18-34$ & NA & Erupted & No & Yes & No & No \\
\hline $\begin{array}{l}\text { Elter et al, },^{20} \\
\quad 2005\end{array}$ & NA & Clinical & $\begin{array}{l}\text { Dental ARIC study } \\
\text { subsample }\end{array}$ & 6,793 & $62 ; 52-74$ & NA & Erupted & No & Yes & No & No \\
\hline $\begin{array}{l}\text { Garaas et al, }{ }^{23} \\
2011\end{array}$ & NA & Clinical & $\begin{array}{l}\text { Dental ARIC study } \\
\text { subsample }\end{array}$ & 2064 & $62 ; 52-74$ & NA & Erupted & Yes & Yes & No & No \\
\hline $\begin{array}{l}\text { Garaas et al, }{ }^{24} \\
2012\end{array}$ & NA & $\begin{array}{l}\text { Clinical and } \\
\text { radiographic }\end{array}$ & $\begin{array}{l}\text { University of Kentucky } \\
\text { and North Carolina } \\
\text { study subsample }\end{array}$ & 409 & $25 ; 22-31$ & NA & Erupted & Yes & Yes & No & No \\
\hline $\begin{array}{l}\text { Jung et al, } \\
2013\end{array}$ & NA & Radiographic & $\begin{array}{l}\text { Pusan National } \\
\text { University Dental } \\
\text { Hospital patients }\end{array}$ & 3,799 & $50 ; 25-92$ & NA & $\begin{array}{c}\text { Erupted and } \\
\text { impacted }\end{array}$ & Yes & Yes & Yes & Yes \\
\hline Li et al, ${ }^{27} 2019$ & NA & Radiographic & $\begin{array}{l}\text { Hospital of Stomatology, } \\
\text { Sun Yat-sen University } \\
\text { patients }\end{array}$ & 276 & $34 ; 16-81$ & 507 & Impacted & No & No & Yes & No \\
\hline $\begin{array}{l}\text { Marques } \\
\text { et al, } \\
2017\end{array}$ & NA & Radiographic & $\begin{array}{l}\text { School of Dentistry, } \\
\text { University of Barcelona } \\
\text { patients }\end{array}$ & 203 & $26 ; 18-45$ & 327 & Impacted & Yes & No & No & No \\
\hline $\begin{array}{l}\text { Moss et al, } \\
2009\end{array}$ & NA & Clinical & $\begin{array}{l}\text { Dental ARIC study } \\
\text { subsample }\end{array}$ & 6,793 & $62 ; 52-74$ & NA & Erupted & No & Yes & No & No \\
\hline $\begin{array}{l}\text { Oenning } \\
\text { et al, } \\
2015\end{array}$ & NA & Radiographic & $\begin{array}{l}\text { Piracicaba Dental School, } \\
\text { University of } \\
\text { Campinas, São Paulo, } \\
\text { patients }\end{array}$ & 116 & $23 ; 14-62$ & 174 & Impacted & No & No & Yes & No \\
\hline $\begin{array}{l}\text { Özeç et al, }{ }^{34} \\
2009\end{array}$ & NA & Radiographic & $\begin{array}{l}\text { Cumhuriyet University, } \\
\text { Turkey, patients }\end{array}$ & 485 & $25 ; 18-49$ & 585 & Impacted & Yes & No & No & No \\
\hline $\begin{array}{l}\text { Schriber } \\
\text { et al, } \\
2019\end{array}$ & NA & Radiographic & $\begin{array}{l}\text { Department of Oral } \\
\text { Surgery and } \\
\text { Stomatology, } \\
\text { University of Bern, } \\
\text { patients }\end{array}$ & 84 & $34 ; 17-77$ & 84 & Impacted & No & No & Yes & No \\
\hline $\begin{array}{l}\text { Sejfija et al, }{ }^{37} \\
2019\end{array}$ & NA & Radiographic & $\begin{array}{l}\text { University of Dentistry } \\
\text { Clinical Center of } \\
\text { Kosovo patients }\end{array}$ & 5,515 & $29 ; 18-77$ & 1,297 & Impacted & Yes & Yes & Yes & Yes \\
\hline $\begin{array}{l}\text { Shugars } \\
\text { et al, }{ }^{38} \\
2004\end{array}$ & NA & $\begin{array}{l}\text { Clinical and } \\
\text { radiographic }\end{array}$ & $\begin{array}{l}\text { University of Kentucky } \\
\text { and North Carolina } \\
\text { study subsample }\end{array}$ & 389 & $27 ; 22-32$ & NA & Erupted & Yes & No & No & No \\
\hline $\begin{array}{l}\text { Syed et al, }{ }^{40} \\
2017\end{array}$ & NA & Radiographic & $\begin{array}{l}\text { College of Dentistry, King } \\
\text { Khalid University, } \\
\text { Abha, Kingdom of } \\
\text { Saudi Arabia, patients }\end{array}$ & 979 & $\mathrm{NA} ; 21-45$ & 333 & Impacted & Yes & No & No & No \\
\hline $\begin{array}{l}\text { Ventä et al, }{ }^{41} \\
2015\end{array}$ & NA & Radiographic & Helsinki Aging Study & 293 & $79 ; 76-86$ & 99 & $\begin{array}{c}\text { Erupted and } \\
\text { impacted }\end{array}$ & Yes & Yes & No & No \\
\hline
\end{tabular}




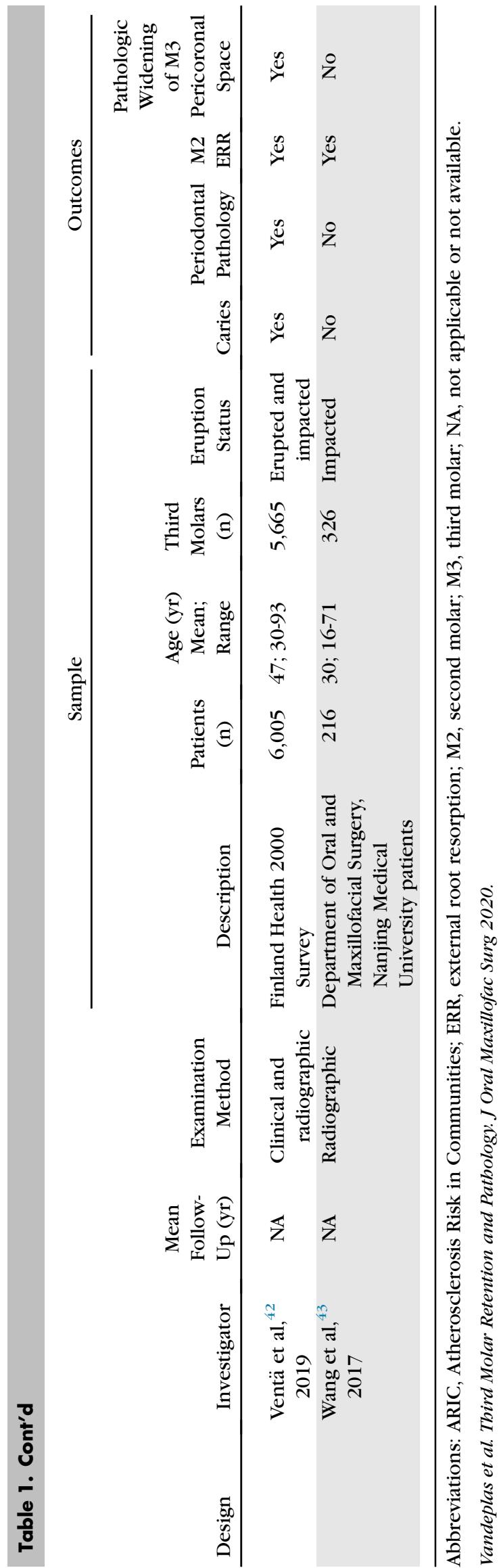

factor that could negatively affect oral health well into later life.

\section{Periodontal Pathology}

Age and, thus, the retention time, appeared to have a significant relationship to periodontal disease prevalence. The series of follow-up studies reported by Blakey et $\mathrm{al}^{10,12-14}$ and White et $\mathrm{al}^{44}$ showed progressively increasing third molar periodontal probing depths (PDs) over time that exceeded $4 \mathrm{~mm}$. During the 4 years of follow-up, 38\% of the patients had PDs of $4 \mathrm{~mm}$ or more in the third molar region, even when all PDs had been low or nonexistent at baseline. ${ }^{13}$ Similarly, Ahmad et $\mathrm{al}^{8}$ reported a $51 \%$ prevalence of third molar PDs of $4 \mathrm{~mm}$ or more at baseline in a population aged 18 to 20 years, with a $10 \%$ increase found 5 years later. Periodontal disease was observed significantly more often in patients older than 25 years. ${ }^{10}$ The overall prevalence of periodontal disease in the included studies ranged from 33 to $61 \%$ for the third molar and 17 to $50 \%$ for the M2D. Fisher et $\mathrm{al}^{22}$ noted that third molars were more affected by periodontal pathology than were first or second molars (56 vs $50 \%$, respectively). In 4 studies, the mandible had been significantly more affected than the maxilla. ${ }^{10,11,13,41}$ Moreover, the periodontal health of the second molar was shown to be negatively affected by retention of the adjacent third molar, in both young and older populations. Two studies by Elter et $\mathrm{al}^{20,21}$ examined 5,831 young patients (age range, 18 to 34 years) and 6,793 older patients (age range, 52 to 74 years). They reported that the odds of a PD greater than $5 \mathrm{~mm}$ for the second molar were 2 and 1.5 times, respectively, greater when the adjacent third molar was present than when it was absent. The odds increased with increasing age. This association between third molar presence and the occurrence of second molar periodontal disease was also reported by Chou et $\mathrm{al}^{15}$ and Nunn et al. ${ }^{32}$ During a follow-up period of more than 25 years, Nunn et $\mathrm{al}^{32}$ found significant differences in the relative risks for second molar pathology in patients with all types of third molar impaction, third molar agenesis, or third molar absence due to earlier removal. Using the absence of the third molars as a reference, the relative risk for an M2D PD greater than $4 \mathrm{~mm}$ was 1.87 for erupted third molars, 6.41 for soft tissue impacted third molars, and 1.60 for bony impacted third molars. In addition, the relative risks for $20 \%$ or more of M2D alveolar bone loss were 1.49 for erupted third molars, 9.15 for soft tissue impacted third molars, and 3.09 for bony impacted third molars.

\section{Second Molar ERR}

Several cross-sectional studies of second molar ERR in the presence of a third molar were available. In general, increasing age, third molar impaction status, and 


\section{Table 2. MAIN CONCLUSIONS FROM INCLUDED REPORTS STRATIFIED BY PATHOLOGY RELATED TO THIRD MOLAR} RETENTION

\begin{tabular}{|c|c|c|}
\hline Outcome & Pathology-Related Results & Reference \\
\hline \multirow[t]{2}{*}{ Caries } & $\begin{array}{l}\text { M3 presence or retention related to presence of } \\
\text { caries in M3 region }\end{array}$ & $\begin{array}{l}9^{*}, 14,15^{*}, 16,18,22,26,27,32^{*}, 34^{*}, 35^{*} \\
\quad 38^{*}, 39,40,41\end{array}$ \\
\hline & $\begin{array}{l}\text { M3 position related to presence of caries in M3 } \\
\text { region }\end{array}$ & $\begin{array}{l}9^{*}, 14,15^{*}, 16,17,26,27^{*}, 32^{*}, 34^{*}, 35^{*}, 40 \text {, } \\
\quad 41\end{array}$ \\
\hline \multirow[t]{2}{*}{ Periodontal pathology } & $\begin{array}{l}\text { M3 presence or retention related to presence of } \\
\text { periodontal pathology in M3 region }\end{array}$ & $\begin{array}{l}8,10^{*}, 11,12^{*}, 14,15^{*}, 16,20,21,22,26,32, \\
\quad 41,44\end{array}$ \\
\hline & $\begin{array}{l}\text { M3 position related to presence of periodontal } \\
\text { pathology in M3 region }\end{array}$ & $14,15^{*}, 16,26,31,32^{*}, 41$ \\
\hline \multirow[t]{2}{*}{ M2 ERR } & $\begin{array}{l}\text { M3 presence or retention related to presence of } \\
\text { M2 ERR }\end{array}$ & $14,27^{*}, 36^{*}, 37,43^{*}$ \\
\hline & M3 position related to presence of M2 ERR & $14,27^{*}, 33,36^{*}, 43^{*}$ \\
\hline \multirow[t]{2}{*}{$\begin{array}{l}\text { Pathologic widening of } \\
\text { M3 pericoronal space }\end{array}$} & $\begin{array}{l}\text { M3 presence or retention related to pathologic } \\
\text { widening of M3 pericoronal space }\end{array}$ & 42 \\
\hline & $\begin{array}{l}\text { M3 position related to pathologic widening of } \\
\text { M3 pericoronal space }\end{array}$ & 42 \\
\hline
\end{tabular}

Abbreviations: ERR, external root resorption; M2, second molar; M3, third molar.

* Studies with statistically significant findings.

Vandeplas et al. Third Molar Retention and Pathology. J Oral Maxillofac Surg 2020.

impacted depth were significantly associated with prevalence of second molar ERR. Differences in second molar ERR prevalence were observed between the studies that investigated patients with a mean age younger or older than 25 years ( 40 to $49 \%^{14,33}$ vs 0.5 to $50 \%,{ }^{19,26,36,37,42}$ respectively). Also, differences between the maxilla and mandible were reported. Li et $\mathrm{al}^{27}$ concluded that second molar ERR is common and significantly more prevalent in the mandible (53\%) than in the maxilla (33\%), a finding contradicted by Sejfija et al. ${ }^{37}$ Sejfija et $\mathrm{al}^{37}$ reported that maxillary second molars showed significantly more severe degrees of resorption. They also reported that the mesial angulation and impaction depth of the third molar were significantly associated with second molar ERR. ${ }^{37}$ Similar significant findings regarding age and third molar orientation were reported by Schriber et al. ${ }^{36}$ In their study, $50 \%$ of the cases were in the maxilla, and the most significant increase in second molar ERR prevalence was found when the third molar was transversely positioned. ${ }^{36}$

\section{Pathologic Widening of Third Molar Pericoronal Space}

A widely varying range of results were reported on the prevalence of a widened third molar pericoronal space. Studies investigating pericoronal pathology in erupted, partially erupted, and impacted third molars reported a prevalence of 0.7 to $13 \% .{ }^{14,26,37}$ These studies included patients ranging in age from 18 to 92 years, and large differences were observed in the cutoff values for defining a widened pericoronal space on panoramic radiographs (range, 2.5 to $4 \mathrm{~mm}$ ). Sejfija et $\mathrm{al}^{37}$ examined mostly young persons (mean age, 29 years) and reported a prevalence of $1.2 \%$ using a 4-mm cutoff on panoramic imaging. In contrast, Eliasson et al, ${ }^{19}$ with a very similar study design but of older subjects (mean age, 43 years) and using a $2.5-\mathrm{mm}$ cutoff, reported a prevalence of $4 \%$. Additionally, the latter study reported that mandibular third molars were more affected than were maxillary third molars. ${ }^{19}$ Of the included studies, only Ventä et al ${ }^{42}$ attributed the presence of pericoronal pathology to the position of the third molar (aberrant orientation and impaction depth).

\section{ASSESSMENT OF METHODOLOGIC QUALITY}

The tool used to assess the methodologic quality of the included studies is presented in Table 3 . The corresponding results are listed in Table 4 and shown in Figure 2. The mean scores per topic of risk of bias could range from 0 to 2 . A higher score indicates a lower risk of bias. A visual assessment of the studies with good, medium or fair, or poor quality per risk of bias domain and topic stratified by the pathology related to third molar retention is provided in Figure 2 . The overall quality was considered fair.

\section{Discussion}

Third molars have been widely discussed and have been the topic of more than 10,000 reports in 


\section{Table 3. RISK OF BIAS TOOL USED TO EVALUATE METHODOLOGIC QUALITY OF INCLUDED STUDIES}

Bias Domain and Definition

Score

Selection bias: study population

Study population represented general population

Study population did not represent general population

Study population did not represent general population and was ill defined

Detection bias: standardization of measurement

Examiners were calibrated and/or used a protocol

Study poorly defined or did not define its examiners

Examiners were not calibrated nor used a protocol

$\sqrt{2}$

Detection bias: method of measurement

Caries

Radiographic and clinical assessment using visual and tactile examination

Only radiographic or only clinical assessment using visual tactile examination

Other methods not considered current clinical standard used

Periodontal pathology

Radiographic and clinical assessment through pocket probing

Only radiographic or only clinical assessment through pocket probing

Other methods not considered current clinical standard used

2

1

0

2

1

M2 ERR

CBCT or intraoral radiographic assessment (periapical, bitewing)

Panoramic radiographic assessment

Other methods not considered current clinical standard used

Pathologic widening of M3 pericoronal space

CBCT or intraoral radiographic assessment with 2-mm cutoff

Panoramic radiographic assessment with $2.5-\mathrm{mm}$ cutoff

Other methods not considered current clinical standard used

Attrition bias: incomplete data

Outcome data for all included subjects complete for entire study duration

Outcome data for included subjects not complete but was clearly discussed

Outcome data clearly missing or inadequately discussed

Reporting bias: selective reporting

Basic data on results adequately reported as defined in methods

Reporting of results raised concerns about data completeness

Reported results clearly incomplete or inadequately reported

\begin{tabular}{l}
2 \\
1 \\
0 \\
\hline 2 \\
1 \\
0 \\
\hline 2 \\
1 \\
0 \\
\hline 2 \\
1 \\
0
\end{tabular}

Abbreviations: CBCT, cone-beam computed tomography; ERR, external root resorption; M2, second molar; M3, third molar.

Vandeplas et al. Third Molar Retention and Pathology. J Oral Maxillofac Surg 2020.

biomedical libraries. However, no consensual guidelines have been developed regarding the clinical management of these teeth. The studies included in the present systematic review covered a period of 30 years, a period in which dental practice and care have evolved tremendously, as have the guidelines for third molar management. Because of the current guidelines discouraging prophylactic removal of third molars, the purpose of the present systematic review was to investigate the occurrence of pathologies associated with the retention of asymptomatic third molars.

The available data revealed that retained asymptomatic third molars will rarely remain disease-free, especially when they have partially erupted. Caries and periodontal disease were by far the most commonly observed pathologic outcomes related to retention of third molars. These pathologies occurred at the third molar itself but were also significantly more prevalent on the M2D when adjacent to a third molar. In accordance with the classic findings by Ash et $\mathrm{al}^{45}$ in 1962, the studies in the present review showed that second molars had more periodontal disease when a third molar was present, and this was also true for caries.

Age also played a significant role. Considering that third molars typically erupt between the ages of 17 and 24 years, it was not surprising that third molar and M2D caries were significantly more prevalent in subjects older than 25 years than in younger subjects and that the prevalence varied widely from 24 to $80 \%$ depending on the age of the subjects. ${ }^{24,38,41}$ 
Table 4. RESULTS OF RISK OF BIAS ASSESSMENT EVALUATING METHODOLOGIC QUALITY OF INCLUDED STUDIES

Risk of Bias Score

\begin{tabular}{lccccc} 
& & Detection Bias: & Detection Bias: & Attrition Bias: & Reporting Bias: \\
Pathology & Selection Bias: & Standardization of & Method of & Incomplete & Selective \\
Study Population & Measurement & Measurement & Data & Reporting \\
\hline
\end{tabular}

\section{Caries}

Ahmad et al, 2008

Al Hobail et al, ${ }^{9} 2019$

Celikoglu et al, ${ }^{14} 2010$

Chou et al, ${ }^{15} 2017$

Chu et al, ${ }^{16} 2003$

Claudia et al, ${ }^{17} 2018$

Divaris et al, ${ }^{18} 2012$

Fisher et al, ${ }^{22} 2012$

Garaas et al, ${ }^{23} 2011$

Garaas et al, ${ }^{24} 2012$

Jung et al, ${ }^{26} 2013$

Marques et al, ${ }^{28} 2017$

Moss et al, ${ }^{30} 2007$

Nunn et al, ${ }^{32} 2013$

Özeç et al, ${ }^{34} 2009$

Pepper et al, ${ }^{35} 2017$

Sejfija et al, ${ }^{37} 2019$

Shugars et al, ${ }^{38} 2004$

Shugars et al, ${ }^{39} 2005$

Syed et al, ${ }^{40} 2017$

Ventä et al, ${ }^{41} 2015$

Ventä et al, ${ }^{42} 2019$

Study Population

Measurement

Measurement

Data

Reporting

Periodontal pathology

Ahmad et al, ${ }^{8} 2008$

Blakey et al, ${ }^{10} 2002$

Blakey et al, ${ }^{12} 2006$

Blakey et al, ${ }^{11} 2007$

Blakey et al, ${ }^{13} 2009$

Celikoglu et al, ${ }^{14} 2010$

Chou et al, ${ }^{15} 2017$

Chu et al, ${ }^{16} 2003$

Eliasson et al, ${ }^{19} 1989$

Elter et al, ${ }^{21} 2004$

Elter et al, ${ }^{20} 2005$

Fisher et al, ${ }^{22} 2012$

Garaas et al, ${ }^{23} 2011$

Garaas et al, ${ }^{24} 2012$

Golden et al, ${ }^{25} 2015$

Jung et al, ${ }^{26} 2013$

Moss et al, ${ }^{30} 2007$

Moss et al, ${ }^{29} 2009$

Nance et al, ${ }^{31} 2006$

Nunn et al, ${ }^{32} 2013$

Sejfija et al, ${ }^{37} 2019$

Ventä et al, ${ }^{41} 2015$

Ventä et al, ${ }^{42} 2019$

White et al, ${ }^{44} 2006$

\begin{tabular}{ll}
1 & 2 \\
1 & 2 \\
1 & 2 \\
1 & 2 \\
1 & 2 \\
1 & 1 \\
1 & 2 \\
1 & 1 \\
1 & 2 \\
1 & 2 \\
1 & 1 \\
1 & 2 \\
1 & 1 \\
1 & 1 \\
0 & 2 \\
1 & 0 \\
1 & 2 \\
1 & 2 \\
1 & 2 \\
1 & 1 \\
1 & 1 \\
1 & 2 \\
\hline
\end{tabular}

$\begin{array}{ll}2 & 1 \\ 2 & 2 \\ 2 & 1 \\ 2 & 2 \\ 2 & 1 \\ 1 & 1 \\ 2 & 2 \\ 1 & 2 \\ 2 & 1 \\ 2 & 2 \\ 1 & 1 \\ 2 & 1 \\ 1 & 1 \\ 1 & 2 \\ 2 & 1 \\ 0 & 1 \\ 2 & 1 \\ 2 & 2 \\ 2 & 2 \\ 1 & 1 \\ 1 & 2 \\ 2 & 2 \\ & \end{array}$

$\begin{array}{ll}1 & 1 \\ 2 & 1 \\ 1 & 1 \\ 2 & 1 \\ 1 & 1 \\ 1 & 1 \\ 2 & 1 \\ 2 & 1 \\ 1 & 1 \\ 2 & 1 \\ 1 & 1 \\ 1 & 1 \\ 1 & 1 \\ 2 & 1 \\ 1 & 1 \\ 1 & 1 \\ 1 & 1 \\ 2 & 1 \\ 2 & 1 \\ 1 & 1 \\ 2 & 1 \\ 2 & 1 \\ & \end{array}$

\begin{tabular}{ll}
1 & 2 \\
1 & 2 \\
1 & 2 \\
1 & 1 \\
1 & 1 \\
1 & 2 \\
1 & 2 \\
1 & 2 \\
1 & 2 \\
1 & 2 \\
1 & 2 \\
1 & 2 \\
1 & 2 \\
1 & 2 \\
1 & 2 \\
1 & 2 \\
1 & 2 \\
1 & 2 \\
1 & 2 \\
1 & 2 \\
1 & 2 \\
\hline & 2 \\
\hline &
\end{tabular}

M2 ERR

Celikoglu et al, ${ }^{14} 2010$

$\begin{array}{ll}1 & 2 \\ 1 & 2 \\ 1 & 2 \\ 1 & 2 \\ 1 & 2 \\ 1 & 2 \\ 1 & 2 \\ 1 & 2 \\ 1 & 1 \\ 1 & 2 \\ 1 & 2 \\ 1 & 1 \\ 1 & 2 \\ 1 & 2 \\ 1 & 1 \\ 1 & 1 \\ 1 & 1 \\ 1 & 2 \\ 1 & 2 \\ 1 & 1 \\ 1 & 2 \\ 1 & 1 \\ 1 & 2 \\ 1 & 2 \\ & \end{array}$

Eliasson et al, ${ }^{19} 1989$

Jung et al, ${ }^{26} 2013$

$\begin{array}{ll}1 & 2 \\ 1 & 1 \\ 1 & 1\end{array}$

\begin{tabular}{|c|c|c|}
\hline 1 & 1 & 2 \\
\hline 1 & 1 & 2 \\
\hline 1 & 1 & 2 \\
\hline 2 & 0 & 0 \\
\hline 2 & 1 & 2 \\
\hline 1 & 1 & 2 \\
\hline 2 & 1 & 1 \\
\hline 1 & 1 & 1 \\
\hline 1 & 1 & 2 \\
\hline 1 & 1 & 2 \\
\hline 1 & 1 & 2 \\
\hline 2 & 1 & 2 \\
\hline 1 & 1 & 2 \\
\hline 2 & 1 & 2 \\
\hline 1 & 0 & 2 \\
\hline 1 & 1 & 2 \\
\hline 1 & 1 & 2 \\
\hline 1 & 1 & 2 \\
\hline 2 & 1 & 2 \\
\hline 2 & 1 & 2 \\
\hline 1 & 1 & 2 \\
\hline 2 & 1 & 2 \\
\hline 2 & 1 & 2 \\
\hline 1 & 1 & 2 \\
\hline 1 & 1 & 2 \\
\hline 1 & 1 & 2 \\
\hline 1 & 1 & 2 \\
\hline
\end{tabular}


Table 4. Cont'd

\begin{tabular}{|c|c|c|c|c|c|}
\hline \multirow[b]{2}{*}{ Pathology } & \multicolumn{5}{|c|}{ Risk of Bias Score } \\
\hline & $\begin{array}{l}\text { Selection Bias: } \\
\text { Study Population }\end{array}$ & $\begin{array}{l}\text { Detection Bias: } \\
\text { Standardization of } \\
\text { Measurement }\end{array}$ & $\begin{array}{c}\text { Detection Bias: } \\
\text { Method of } \\
\text { Measurement }\end{array}$ & $\begin{array}{c}\text { Attrition Bias: } \\
\text { Incomplete } \\
\text { Data }\end{array}$ & $\begin{array}{c}\text { Reporting Bias: } \\
\text { Selective } \\
\text { Reporting }\end{array}$ \\
\hline Li et al, ${ }^{27} 2019$ & 1 & 2 & 2 & 1 & 2 \\
\hline Oenning et $\mathrm{al}^{33}{ }^{33} 2015$ & 1 & 1 & 2 & 1 & 2 \\
\hline Schriber et al, ${ }^{36} 2019$ & 1 & 1 & 2 & 1 & 2 \\
\hline Sejfija et al,,$^{37} 2019$ & 1 & 2 & 1 & 1 & 2 \\
\hline Ventä et al, ${ }^{42} 2019$ & 1 & 2 & 1 & 1 & 2 \\
\hline Wang et al, ${ }^{43} 2017$ & 1 & 1 & 2 & 1 & 2 \\
\hline \multicolumn{6}{|l|}{$\begin{array}{l}\text { Pathologic widening of } \\
\text { M3 pericoronal space }\end{array}$} \\
\hline Celikoglu et al,,$^{14} 2010$ & 1 & 2 & 1 & 1 & 2 \\
\hline Eliasson et al, ${ }^{19} 1989$ & 1 & 1 & 1 & 1 & 2 \\
\hline Jung et al,,$^{26} 2013$ & 1 & 1 & 0 & 1 & 2 \\
\hline Sejfija et al, ${ }^{37} 2019$ & 1 & 2 & 0 & 1 & 2 \\
\hline Ventä et al, ${ }^{42} 2019$ & 1 & 2 & 1 & 1 & 2 \\
\hline
\end{tabular}

Abbreviations: ERR, external root resorption; M2, second molar; M3, third molar.

Vandeplas et al. Third Molar Retention and Pathology. J Oral Maxillofac Surg 2020.

Similarly, periodontal disease nearly doubled in those older than 25 years. ${ }^{10}$ The prevalence of deep third molar periodontal pockets ( $\mathrm{PD}$ of $\geq 5 \mathrm{~mm}$ ) was surprisingly greater than would have been be expected from the results from the NHANES III. When examining older ages, fewer than $2 \%$ of the subjects aged 52 to 74 years were free of periodontal pathology and caries in the Dental ARIC study. ${ }^{23}$

Several studies have reported that third or second molar pathology was dependent on the impaction status of the third molar. ${ }^{8,32,38,44}$ In particular, caries and periodontal pathology were more prevalent in the presence of a third molar and even more so when the third molar had partially erupted. Because caries and periodontal disease are primarily caused by dental plaque, these phenomena can be explained by the difficulties in maintaining oral hygiene distally in the mouth and, consequently, the accumulation of plaque. This can be aggravated when the third molar has only partially erupted, because this position will undermine the second molar's gingival seal. ${ }^{46}$

However, prospective longitudinal studies are lacking on the topics of second molar ERR and pathologic widening of the pericoronal space. The studies that investigated these pathologies were all cross-sectional in design, compromising the opportunity to inquire into the development of these pathologies over time. Nonetheless, several of these cross-sectional studies reported a significant association with older age and the prevalence of second molar ERR. Mesial bony impaction was not only associated with a greater prevalence, but also with more severe resorption. ${ }^{27,36,43}$
A major limitation of the included studies were the study samples, which were not very generalizable to the overall population. All included prospective studies had used subsamples of longitudinal trials. The data had originally been prospectively collected; thus, the studies analyzing these data were, by definition, also prospective. To the best of our knowledge, no prospective studies using their own original sample data have been reported that would fit the criteria for the present review. By far the most used sample originated from the University of Kentucky and University of North Carolina ( 10 of 12 prospective studies and 13 of all 37 studies). Thus, it is likely that data from the same subjects were used in multiple of the included reports. Other studies included patients from private practices or academic institution clinical departments or subsamples of various other studies. None of the samples were representative of the general population. Research on third molar pathology has nearly always been performed on a clinical sample of patients visiting the dental department of a hospital seeking advice on one or more oral events. Patients with symptom-free third molars can be difficult to reach. Nevertheless, it is important to state that absence of symptoms does not equal the absence of disease, which was clearly and repeatedly demonstrated by Dodson and Marciani. ${ }^{47-49}$

Another limitation was the method by which the disease outcomes were measured, especially for caries and periodontal disease. These should ideally be assessed both clinically and radiographically, preferably with visual and tactile assessment (ie, probing) and 


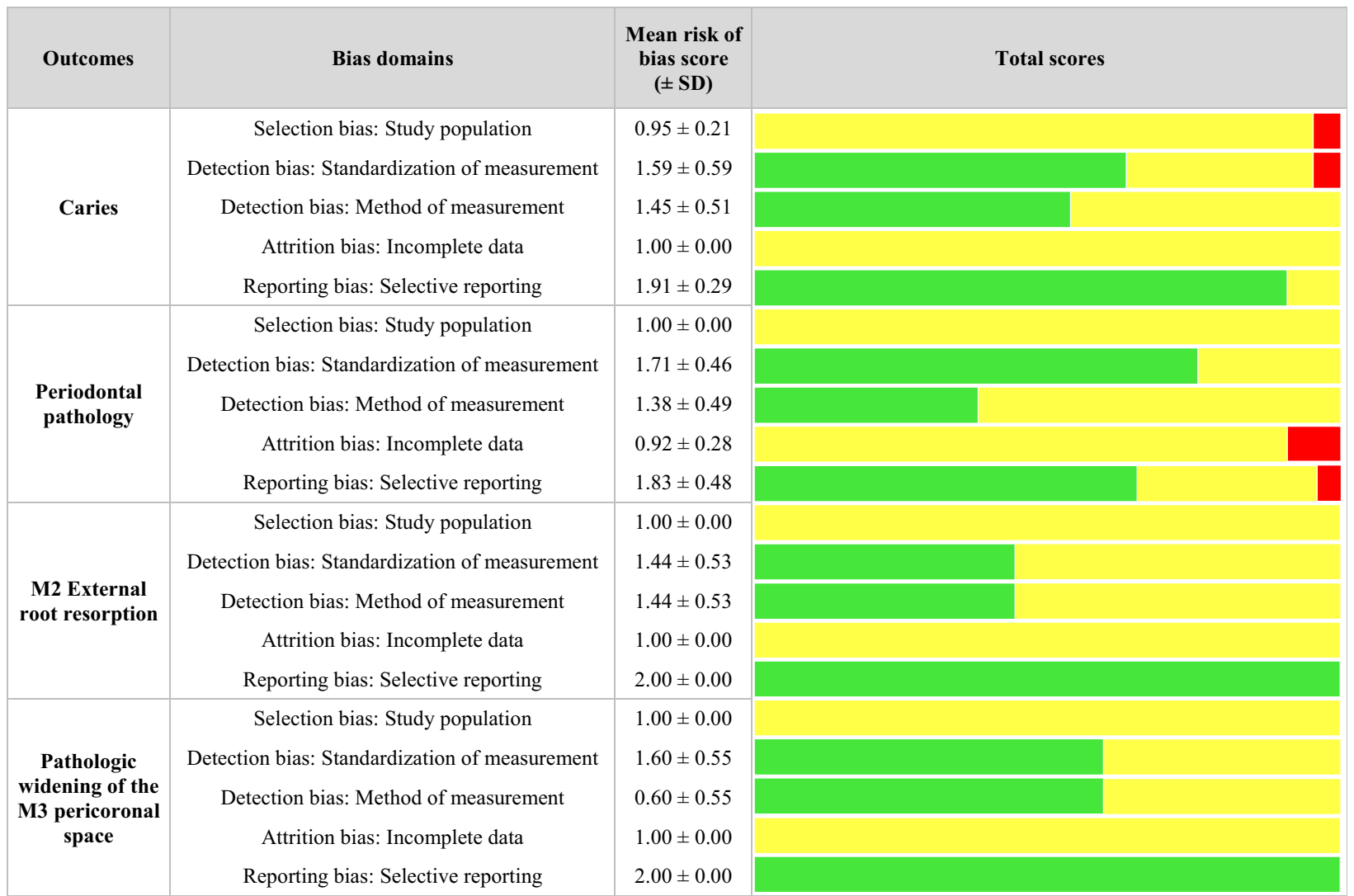

FIGURE 2. Visual assessment of the risk of bias of studies stratified by pathology. The overall quality of the included studies was considered medium or fair). Each domain was given a numerical value of 2,1 or 0 , indicating a low, medium, or high risk of bias, respectively. For visual assessment of the risk of bias, the values were given a corresponding color, indicating good (green), medium or fair (yellow), or poor (red) quality. SD, standard deviation.

Vandeplas et al. Third Molar Retention and Pathology. J Oral Maxillofac Surg 2020.

intraoral radiography (ie, periapical, bitewing). Most (20 of 35) of the reports studying these pathologies used only one of these methods to measure the disease outcomes. This not only impaired the disease measurements, but also limited the possibility of assessing the position of the impacted third molar. For second molar ERR and pericoronal widening of the third molar pericoronal space, the method of choice has been conebeam computed tomography (CBCT) or intraoral radiography. ${ }^{50,51}$ Panoramic radiographs have been considered a valid, although less suitable, method to accurately assess these pathologies. Thus, the wide variability in the prevalence of second molar ERR (range, 0.5 to $50 \%$ ) can be attributed to the study by Eliasson et al, ${ }^{19}$ which used 2-dimensional panoramic radiographs to assess resorption. In contrast, Schriber et $\mathrm{al}^{36}$ evaluated the 3-dimensional extent of resorption using CBCT. Furthermore, when evaluating widening of the pericoronal space (prevalence range, 0.7 to $13 \%$ ), the cutoff for the presence of pathology should be set to greater than $2.5 \mathrm{~mm}$ for panoramic images and greater than $2 \mathrm{~mm}$ for CBCT and intraoral ra- diographs. However, of the 5 studies that investigated this pathology, 2 used cutoff values greater than 2.5 (Ventä et al, ${ }^{42} 3$ to $5 \mathrm{~mm}$; Sejfija et al, ${ }^{37} 4 \mathrm{~mm}$ ). ${ }^{37,42}$ Because of the differences in methods and different age categories examined in the included studies, large variations were found in the disease prevalence. To critically evaluate the quality of the selected methods of measurement, we included an extra category in the risk of bias assessment. Moreover, the reports that failed to describe the distinction between maxillary and mandibular observations might further substantiate the wide variation in results. In these cases, a lower prevalence of a certain pathology in the upper or lower jaw could mask or confound a greater prevalence in the other jaw, and vice versa. ${ }^{19,36}$

The included studies were classified by 4 main pathologies: caries, periodontal pathology, second molar ERR, and pathologic widening of the third molar pericoronal space. These 4 pathologies associated with the third molars should not be considered exhaustive but, rather, were the most frequently investigated pathologies in the included studies. The present review 
did not examine the pathologies that have been associated with a widening of the third molar pericoronal space, such as various cysts and tumors ${ }^{52,53}$ or abscesses and systemic inflammation associated with third molar retention. ${ }^{54}$ Mandibular fractures and other complications were also not investigated. ${ }^{52}$ Crowding of the anterior incisors has long been considered a consequence of third molar retention; however, it is now understood that third molars cannot distort the dental alignment to such a degree. ${ }^{55-57}$

Data on the long-term effects of retaining third molars have remained limited. The average follow-up time was only 4 years, which is arguably insufficient to make accurate predictions on the future development of pathology. Moreover, studies that had followed third molar status reported that the third molars frequently had to be removed during the follow-up period. ${ }^{58}$ This substantiates the hypothesis that third molars will rarely remain disease-free over a lifetime.

To date, no systematic approaches are available to allow for satisfactory predictions regarding third molar disease development, with consideration of impaction status, patient's oral hygiene, and the overall clinical picture. Several international guidelines on the clinical management of third molars have been reported to aid clinicians with treatment decisions. These have included the 2000 NICE guidelines from the United Kingdom, the 2000 SIGN guidelines, and the 2012 KCE report. ${ }^{3-5}$ After the publication of these guidelines, the number of surgical third molar removals temporarily decreased for some years; however, they have again increased to a level comparable to that in the mid-1990s. ${ }^{59}$ Thus, patients have been, on average, 6 years older when undergoing this surgery than in the past. ${ }^{60,61}$ This might lead to a reversed effect of increasing the risk of complications associated with older age and unfavorable conditions on surgical removal. ${ }^{62,63}$ The guidelines have mainly advised against the prophylactic removal of third molars because of the lack of clinical evidence that third molars will eventually develop pathology when retained. With this argumentum ad ignorantiam approach, the guidelines, thus, concluded that retention systematically outperforms extraction, despite providing no evidence to suggest that these teeth would remain free of pathology and symptoms. ${ }^{64}$ In the present ongoing disagreement, clinicians have largely relied on their own expertise and beliefs in their clinical decision making. ${ }^{2,65}$ Thus, great variation has continued to exist among clinicians regarding their evaluation and beliefs regarding the need for third molar removal.

In conclusion, the present systematic review was conducted to explore the current data regarding the pathologies associated with the retention of asymptomatic third molars. The results of our systematic re- view have shown that medium to fair quality evidence is available that has demonstrated that pathology in these teeth is common and, moreover, that retention of the third molar is significantly associated with an increased risk of pathology in the second molar, especially with partially erupted and/or mesially inclined, mandibular third molars. Well-designed prospective follow-up studies are needed to substantiate the clinical management (removal or retention) of asymptomatic third molars.

\section{References}

1. Carter K, Worthington S: Predictors of third molar impaction: A systematic review and meta-analysis. J Dent Res 95:267, 2016

2. Knutsson K, Brehmer B, Lysell L, Rohlin M: General dental practitioners' evaluation of the need for extraction of asymptomatic mandibular third molars. Community Dent Oral Epidemiol 20: 347,1992

3. National Institute for Health and Clinical Excellence. Guidance on the extraction of wisdom teeth. Technology Appraisal Guidance. Available at: https://www.nice.org.uk/guidance/ta1. Accessed March 18, 2020

4. Scottish Intercollegiate Guidelines Network: Management of unerupted and impacted third molar teeth-A national clinical guideline. SIGN 43. Available at: http://www.exodontia.info/ files/SIGN_Unerupted_Impacted_3rd_Molars_Quick_Refernce_ Guide.pdf. Accessed March 18, 2020

5. Stordeur S, Eyssen M: Prophylactic removal of pathology-free wisdom teeth: Rapid assessment. Federaal Kenniscentrum voor Gezondheidszorg KCE Report 182A, 2012. Available at: https://kce.fgov.be/sites/default/files/atoms/files/KCE_182C_ wisdom_teeth.pdf. Accessed March 18, 2020

6. Liberati A, Altman DG, Tetzlaff J, et al: The PRISMA statement for reporting systematic reviews and meta-analyses of studies that evaluate health care interventions: Explanation and elaboration. J Clin Epidemiol 62:1, 2009

7. Higgins JPT, Altman DG, Gotzsche PC, et al: The Cochrane Collaboration's tool for assessing risk of bias in randomised trials. BMJ 343:d5928, 2011

8. Ahmad N, Gelesko S, Shugars D, et al: Caries experience and periodontal pathology in erupting third molars. J Oral Maxillofac Surg 66:948, 2008

9. Al Hobail SQ, Baseer MA, Ingle NA, et al: Evaluation of distal caries of the second molars in the presence of third molars among Saudi patients. J Int Soc Prev Community Dent 9:505, 2019

10. Blakey GH, Marciani RD, Haug RH, et al: Periodontal pathology associated with asymptomatic third molars. J Oral Maxillofac Surg 60:1227, 2002

11. Blakey GH, Hull DJ, Haug RH, et al: Changes in third molar and nonthird molar periodontal pathology over time. J Oral Maxillofac Surg 65:1577, 2007

12. Blakey GH, Jacks MT, Offenbacher S, et al: Progression of periodontal disease in the second/third molar region in subjects with asymptomatic third molars. J Oral Maxillofac Surg 64: 189, 2006

13. Blakey GH, Golden BA, White RP Jr, et al: Changes over time in the periodontal status of young adults with no third molar periodontal pathology at enrollment. J Oral Maxillofac Surg 67:2425, 2009

14. Celikoglu M, Miloglu O, Kazanci F: Frequency of agenesis, impaction, angulation, and related pathologic changes of third molar teeth in orthodontic patients. J Oral Maxillofac Surg 68: 990, 2010

15. Chou Y-H, Ho P-S, Ho K-Y, et al: Association between the eruption of the third molar and caries and periodontitis distal to the second molars in elderly patients. Kaohsiung J Med Sci 33: 246,2017 
16. Chu FCS, Li TKL, Lui VKB, et al: Prevalence of impacted teeth and associated pathologies-A radiographic study of the Hong Kong Chinese population. Hong Kong Med J 9:158, 2003

17. Claudia A, Barbu H, Adi L, et al: Relationship between third mandibular molar angulation and distal cervical caries in the second molar. J Craniofac Surg 29:2267, 2018

18. Divaris K, Fisher EL, Shugars DA, White RP Jr: Risk factors for third molar occlusal caries: A longitudinal clinical investigation. J Oral Maxillofac Surg 70:1771, 2012

19. Eliasson S, Heimdahl A, Nordenram A: Pathological changes related to long-term impaction of third molars: A radiographic study. Int J Oral Maxillofac Surg 18:210, 1989

20. Elter JR, Offenbacher S, White RP Jr, Beck JD: Third molars associated with periodontal pathology in older Americans. J Oral Maxillofac Surg 63:179, 2005

21. Elter JR, Cuomo CJ, Offenbacher S, White RP Jr: Third molars associated with periodontal pathology in the Third National Health and Nutrition Examination Survey. J Oral Maxillofac Surg 62:440, 2004

22. Fisher EL, Garaas R, Blakey GH, et al: Changes over time in the prevalence of caries experience or periodontal pathology on third molars in young adults. J Oral Maxillofac Surg 70:1016, 2012

23. Garaas R, Moss KL, Fisher EL, et al: Prevalence of visible third molars with caries experience or periodontal pathology in middle-aged and older Americans. J Oral Maxillofac Surg 69: 463,2011

24. Garaas RN, Fisher EL, Wilson GH, et al: Prevalence of third molars with caries experience or periodontal pathology in young adults. J Oral Maxillofac Surg 70:507, 2012

25. Golden BA, Baldwin C, Sherwood C, et al: Monitoring for periodontal inflammatory disease in the third molar region. J Oral Maxillofac Surg 73:595, 2015

26. Jung $\mathrm{Y}-\mathrm{H}, \mathrm{Cho} \mathrm{B}-\mathrm{H}$ : Prevalence of missing and impacted third molars in adults aged 25 years and above. Imaging Sci Dent 43:219, 2013

27. Li D, Tao Y, Cui M, et al: External root resorption in maxillary and mandibular second molars associated with impacted third molars: A cone-beam computed tomographic study. Clin Oral Investig 23:4195, 2019

28. Marques J, Montserrat-Bosch M, Figueiredo R, et al: Impacted lower third molars and distal caries in the mandibular second molar: Is prophylactic removal of lower third molars justified? J Clin Exp Dent 9:e794, 2017

29. Moss KL, Oh ES, Fisher E, et al: Third molars and periodontal pathologic findings in middle-age and older Americans. J Oral Maxillofac Surg 67:2592, 2009

30. Moss KL, Beck JD, Mauriello SM, et al: Third molar periodontal pathology and caries in senior adults. J Oral Maxillofac Surg 65:103, 2007

31. Nance PE, White RP Jr, Offenbacher S, et al: Change in third molar angulation and position in young adults and follow-up periodontal pathology. J Oral Maxillofac Surg 64:424, 2006

32. Nunn ME, Fish MD, Garcia RI, et al: Retained asymptomatic third molars and risk for second molar pathology. J Dent Res 92:1095, 2013

33. Oenning ACC, Sousa Melo SL, Groppo FC, Haiter-Neto F: Mesial inclination of impacted third molars and its propensity to stimulate external root resorption in second molars-A cone-beam computed tomographic evaluation. J Oral Maxillofac Surg 73: 379,2015

34. Özeç I, Hergüner Siso S, Taşdemir U, et al: Prevalence and factors affecting the formation of second molar distal caries in a Turkish population. Int J Oral Maxillofac Surg 38:1279, 2009

35. Pepper T, Grimshaw P, Konarzewski T, Combes J: Retrospective analysis of the prevalence and incidence of caries in the distal surface of mandibular second molars in British military personnel. Br J Oral Maxillofac Surg 55:160, 2017

36. Schriber M, Rivola M, Leung YY, et al: Risk factors for root resorption of second molars associated with impacted mandibular third molars. Int J Oral Maxillofac Surg 48:801, 2019
37. Sejfija Z, Koani F, Macan D: Prevalence of pathologies associated with impacted third molars in Kosovar population: An orthopanthomography study. Acta Stomatol Croat 53:72, 2019

38. Shugars DA, Jacks MT, White RP Jr, et al: Occlusal caries experience in patients with asymptomatic third molars. J Oral Maxillofac Surg 62:973, 2004

39. Shugars DA, Elter JR, Jacks MT, et al: Incidence of occlusal dental caries in asymptomatic third molars. J Oral Maxillofac Surg 63: 341,2005

40. Syed KB, Alshahrani FS, Alabsi WS, et al: Prevalence of distal caries in mandibular second molar due to impacted third molar J Clin Diagn Res 11:ZC28, 2017

41. Ventä I, Kylätie E, Hiltunen K: Pathology related to third molars in the elderly persons. Clin Oral Investig 19:1785, 2015

42. Ventä I, Vehkalahti MM, Suominen AL: What kind of third molars are disease-free in a population aged 30 to 93 years? Clin Oral Investig 23:1015, 2019

43. Wang D, He X, Wang Y, et al: External root resorption of the second molar associated with mesially and horizontally impacted mandibular third molar: Evidence from cone beam computed tomography. Clin Oral Investig 21:1335, 2017

44. White RP Jr, Offenbacher S, Blakey GH, et al: Chronic oral inflammation and the progression of periodontal pathology in the third molar region. J Oral Maxillofac Surg 64:880, 2006

45. Ash MM, Costich ER, Hayward J: A study of periodontal hazards of third molars. J Periodontol 33:209, 1962

46. Toedtling V, Yates JM: Revolution vs status quo? Nonintervention strategy of asymptomatic third molars causes harm. Br Dent J 219:11, 2015

47. Dodson TB: How many patients have third molars and how many have one or more asymptomatic, disease-free third molars? J Oral Maxillofac Surg 70:S4, 2012

48. Marciani RD, Dodson TB: Is there pathology associated with asymptomatic third molars? J Oral Maxillofac Surg 70:S15, 2012

49. Dodson TB: The management of the asymptomatic, disease-free wisdom tooth: Removal versus retention. Atlas Oral Maxillofac Surg Clin North Am 20:169, 2012

50. Oenning ACC, Neves FS, Alencar PNB, et al: External root resorption of the second molar associated with third molar impaction: Comparison of panoramic radiography and cone beam computed tomography. J Oral Maxillofac Surg 72:1444, 2014

51. Langlais RP, Langland O, Nortje CJ: Diagnostic Imaging of the Jaws. Baltimore, Williams \& Wilkins, 1995

52. McCoy JM: Complications of retention: Pathology associated with retained third molars. Atlas Oral Maxillofac Surg Clin North Am 20:177, 2012

53. Yildirim G, Ataoğlu H, Mihmanli A, et al: Pathologic changes in soft tissues associated with asymptomatic impacted third molars. Oral Surg Oral Med Oral Pathol Oral Radiol Endod 106: 838,2008

54. Offenbacher S, Beck JD, Moss KL, et al: What are the local and systemic implications of third molar retention? J Oral Maxillofac Surg 70:S58, 2012

55. Ades AG, Joondeph DR, Little RM, Chapko MK: A long-term study of the relationship of third molars to changes in the mandibular dental arch. Am J Orthod Dentofacial Orthop 97: 323,1990

56. Buschang PH, Shulman JD: Incisor crowding in untreated persons 15-50 years of age: United States, 1988-1994. Angle Orthod $73: 502,2003$

57. Harradine NW, Pearson MH, Toth B: The effect of extraction of third molars on late lower incisor crowding: A randomized controlled trial. Br J Orthod 25:117, 1998

58. Ventä I, Ylipaavalniemi P, Turtola L: Clinical outcome of third molars in adults followed during 18 years. J Oral Maxillofac Surg 62:182, 2004

59. McArdle LW, Renton T: The effects of NICE guidelines on the management of third molar teeth. Br Dent J 213:E8, 2012

60. Chiapasco M, Crescentini M, Romanoni G, Andreasen JO: Germectomy or delayed removal of mandibular impacted third 
molars: The relationship between age and incidence of complications. J Oral Maxillofac Surg 53:418, 1995

61. Renton T, Al-Haboubi M, Pau A, et al: What has been the United Kingdom's experience with retention of third molars? J Oral Maxillofac Surg 70:S48, 2012

62. Bouloux GF, Steed MB, Perciaccante VJ: Complications of third molar surgery. Oral Maxillofac Surg Clin North Am $19: 117,2007$
63. Pogrel MA: What is the effect of timing of removal on the incidence and severity of complications? J Oral Maxillofac Surg 70:S37, 2012

64. Dodson TB: Those who ignore the evidence are doomed to misuse it. Gen Dent 61:22, 2013

65. Kostopoulou O, Brickley MR, Shepherd JP, et al: Agreement between practitioners concerning removal of asymptomatic third molars. Community Dent Health 14:129, 1997 


\section{Appendix 1}

Search Syntax for Each Database (Search Last Performed April 2, 2020):

SEARCH PubMed:

Domain:

((("molar, third"[MeSH Terms] OR wisdom teeth[Title/Abstract]) OR wisdom tooth[Title/Abstract]) OR (third molar[Title/Abstract] OR third molars[Title/Abstract])) OR (3rd molar[Title/Abstract] OR 3rd molars[Title/Abstract])

AND Outcome:

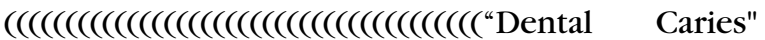
[Mesh:NoExp]) OR "Osteomyelitis"[Mesh:NoExp]) OR Periodontal Diseases[MeSH Terms]) OR Tooth Resorption[MeSH Terms]) OR Jaw Cysts[MeSH Terms]) OR Odontogenic tumors[MeSH Terms]) OR Jaw Neoplasms[MeSH Terms]) OR Jaw Fractures [MeSH Terms]) OR Tooth Extraction[MeSH Terms]) OR Trigeminal Nerve Injuries[MeSH Terms]) OR caries[Title/Abstract]) OR decay[Title/Abstract]) OR carious[Title/Abstract]) OR periodontal[Title/ Abstract]) OR periodontitis[Title/Abstract]) OR resorption [Title/Abstract]) OR inflammation [Title/Abstract]) OR inflammatory[Title/Abstract]) OR pericoronitis[Title/Abstract]) OR abcess[Title/Abstract]) OR osteomyelitis[Title/Abstract]) OR cyst*[Title/Abstract]) OR tumor*[Title/Abstract]) OR tumour*[Title/Abstract]) OR neoplasm*[Title/Abstract]) OR carcinoma[Title/Abstract]) OR crowding[Title/Abstract]) OR removed[Title/Abstract]) OR removal[Title/Abstract]) OR extraction[Title/Abstract]) OR extracted[Title/Abstract]） OR patholog*[Title/Abstract]) OR symptoms[Title/Abstract]) OR symptomatic[Title/Abstract]) OR disease[Title/Abstract]) OR diseased[Title/Abstract]) OR nerve[Title/Abstract]) OR neural[Title/Abstract]) OR neuro*[Title/Abstract])

OR fracture*[Title/Abstract]

Final:

\#domain AND \#outcome

\section{SEARCH EMBASE:}

\#1: 'third molar"':ab,ti OR 'wisdom tooth':ab,ti OR 'wisdom teeth':ab,ti OR '3rd molar'':ab,ti

\#2: 'dental caries'/exp OR 'periodontal disease'/exp OR 'tooth abscess'/exp OR 'osteomyelitis'/exp OR 'jaw cyst'/exp OR 'jaw tumor'/exp OR 'jaw fracture'/exp OR 'crowding (tooth)'/exp OR 'tooth extraction'/exp OR 'trigeminal nerve injury'/exp OR 'caries':ab,ti OR 'carious':ab,ti OR 'decay':ab,ti OR 'periodontal':ab,ti OR 'periodontitis':ab,ti OR 'resorption':ab,ti OR 'inflammation':ab,ti OR 'inflammatory':ab,ti OR 'pericoronitis':ab,ti OR 'osteomyelitis':ab,ti OR 'cyst":ab,ti OR 'abscess':ab,ti OR 'tumor*':ab,ti OR 'tumour*':ab,ti OR 'carcinoma':ab,ti OR 'neoplasm*':ab,ti OR 'patholog*':ab,ti OR 'symptoms':ab,ti OR 'symptomatic':ab,ti OR 'disease':ab,ti OR 'diseased':ab,ti OR 'extracted':ab,ti OR 'extraction':ab,ti OR 'removed':ab,ti OR 'removal':ab,ti OR 'crowding':ab,ti OR 'nerve':ab,ti OR 'neural':ab,ti OR 'neuro*':ab,ti OR 'fracture':ab,ti

Final:

\#1 AND \#2

\section{SEARCH COCHRANE LIBRARY:}

\#1: Mesh term "third molar"

\#2: "third molar" :ab,ti OR "wisdom tooth":ab,ti OR

"wisdom teeth":ab,ti OR "3rd molar":ab,ti

\#3: \#1 OR \#2

\#4: Mesh "dental caries" (NoExp)

\#5: Mesh "Periodontal diseases"

\#6: Mesh "Tooth resorption"

\#7: Mesh "Osteomyelitis" (NoExp)

\#8: Mesh "Jaw cysts"

\#9: Mesh "Odontogenic tumors"

\#10: Mesh "Jaw neoplasms"

\#11: Mesh "Tooth extraction"

\#12: Mesh "Trigeminal Nerve Injuries"

\#13: Mesh "Jaw Fractures"

\#14: \#4 OR ... \#13

\#15: “caries":ab,ti OR "decay":ab,ti OR "carious":ab,ti OR "periodontal":ab,ti OR "periodontitis":ab,ti OR "resorption":ab,ti OR "inflammation":ab,ti OR "inflammatory":ab,ti OR "pericoronitis":ab,ti OR "osteomyelitis":ab,ti OR “cyst*":ab,ti OR "abscess":ab,ti OR "tumor":ab,ti OR "tumour*"ab,ti OR "neoplas$\mathrm{m}^{*}$ :ab,ti OR "carcinoma":ab,ti OR "removed":ab,ti OR "removal":ab,ti OR "extraction":ab,ti OR "extracted":ab,ti OR "patholog*":ab,ti OR "symptoms":ab,ti OR "symptomatic":ab,ti OR "disease":ab,ti OR "diseased":ab,ti OR "crowding":ab,ti OR "nerve":ab,ti OR "neural":ab,ti OR "neuro":ab,ti OR "fracture":ab,ti

\#16: \#14 OR \#15

\#17: \#3 AND \#16 